\title{
Racial variation in diabetes mellitus in Japanese and Caucasians living in Hawaii
}

\author{
MADELEINE J. GOODMAN,* CHIN S. CHUNG, $†$ and FRED GILBERT, Jr $\ddagger$
}

\begin{abstract}
Summary. Comparisons were made between diabetic and control groups in Japanese and Caucasians living in Honolulu, Hawaii. The study was performed on the multiphasic screening records of 109 diagnosed diabetics and 173 healthy controls in Japanese, and 69 diagnosed diabetics and 326 healthy controls in Caucasians. Discriminant function analysis was employed with relevant anthropometric, medical, and biochemical variables. The common set of significant discriminant variables were: diabetic sib, a history of high blood pressure, systolic blood pressure, urine sugar, glucose over $190 \mathrm{mg} \%$, and serum glutamic-oxalacetic transaminase, with age and sex effects fitted. The data suggested that heterogeneity exists between the two racial groups in the relationships of some of these variables with the disease.
\end{abstract}

Considerable attention has recently been given to basic differences between Asian and Western peoples in the epidemiology and physiopathology of diabetes mellitus (Tsuji and Wada, 1971). In particular, distinctive features of diabetes mellitus in Japan as compared with Western countries have been noted: the preponderance of male diabetics (Rudnick and Anderson, 1962; Kuzuya and Kosaka, 1971), the rarity of juvenile diabetics (Kuzuya and Kosaka, 1971), and the considerably lower mortality ratio of deaths from diabetes to deaths from all other causes (Okamoto, Hazama, and Yamasaki, 1971) in Japan in contrast to the United States (Bell, 1960). Further, a substantially lower rate of mortality from cardio-renal-vascular lesions was observed among Japanese (Kuzuya and Kosaka, 1971) than among American diabetics (American Diabetes Association, 1960).

Differences in nutritional status and nutrient consumption patterns in Japan and the United States have been implicated in the explanation of the observed differences of diabetes disease pattern between the two countries (Shigeta et al, 1971). While there is no direct evidence that differences in diabetes mortality rates and in severity of arterio-

\footnotetext{
Received 9 April 1974.

* Department of Genetics, University of Hawaii, 1960 East-West Road, Honolulu, Hawaii 96822, USA.

† Departments of Public Health Sciences and Genetics, University of Hawaii, 1960 East-West Road, Honolulu, Hawaii 96822, USA.

$¥$ Department of Public Health Sciences, University of Hawaii, and Pacific Health Research Institute, Honolulu, Hawaii, USA.
}

sclerotic complications in Japanese diabetes can be attributed to the Japanese diet, the mean blood sugar level as well as the prevalence of diabetes are higher in Japanese living in Hawaii and California where they have somewhat modified their typical Japanese diet (Stemmerman, 1970; Wenkam and Wolff, 1970; Tillotson et al, 1973).

A survey in Hawaii by Sloan (1963) noted differences in the racial prevalence of diabetes among 38,103 employed persons screened by a $2 \frac{1}{2}$ hour post-prandial blood glucose determination. Ageadjusted rates for Caucasians were considerably lower $(7 \cdot 3 / 1000)$ than for Japanese $(20 \cdot 1 / 1000)$. However, the lack of medical data prevented further inference on the observed ethnic differences.

The objective of the present investigation is to examine the type and extent of racial variation with respect to diabetes between the Japanese and Caucasian groups living in the single macro-environment of Honolulu. Of the many racial groups in Hawaii, the Japanese and Caucasians are present in sufficiently large numbers for enough diabetics to be studied within each group.

Data have been made available by the Pacific Health Research Institute, Honolulu. These are the results of a multiphasic health screening program performed at Straub Clinic on diabetic and non-diabetic individuals of both races between 1969-71. The samples present a unique opportunity to make interracial comparisons since their socio-economic standing is roughly comparable as 
measured by ethnic distribution in major occupations (Lind, 1967). The availability of comprehensive laboratory test results and detailed health profiles on each subject allow a detailed comparison of diabetes disease patterns between the two groups.

\section{Materials and methods}

Subjects. A series of diagnosed diabetic cases and healthy controls were assembled separately in Japanese and Caucasian groups from the medical records of 3956 Caucasians and 2508 Japanese individuals who underwent multiphasic screening at Straub Clinic in Honolulu. From the Japanese group, the multiphasic screening records of 109 diagnosed diabetics and 173 healthy controls were obtained. From the Caucasian group records of 69 diagnosed diabetics and 326 healthy controls were selected.

Cases were defined as those who were diagnosed as maturity-onset diabetics on the basis of a confirmed history of the disease or after examination by a physician upon a laboratory finding of a 50-g load one-hour blood glucose level in excess of $300 \mathrm{mg} \%$. Controls were defined as those who were found healthy upon physical examination, and whose laboratory findings were normal.

For all subjects, a medical profile was assembled which included: a complete personal medical history, a family history of major common diseases, anthropometric data, and laboratory findings.

Factors considered. The variables considered in this analysis are listed in Table I. The justification for the selection of the variables was the potential relevance of the available information in the records of individuals screened towards elucidating factors associated with the development of diabetes mellitus. The variables listed are divisible into seven categories: (1) personal medical history $\left(\mathbf{X}_{1}-\mathbf{X}_{3}\right)$, (2) family history of diabetes $\left(\mathbf{X}_{4}-\mathbf{X}_{7}\right)$, (3) sex $\left(\mathbf{X}_{8}\right),(4)$ age and age squared $\left(\mathbf{X}_{9}-\mathbf{X}_{10}\right),(5)$ anthropometric or physical measurements $\left(\mathrm{X}_{11}-\mathrm{X}_{15}\right)$, (6) urine test results $\left(\mathbf{X}_{16}-\mathbf{X}_{18}\right)$, and (7) blood test results $\left(\mathrm{X}_{19}-\mathrm{X}_{33}\right)$.

The details of the techniques used in the laboratory tests are as follows. Urine sugar levels were measured by the glucose oxidase paper strip method (Free $e t a l$, 1957a) with a range of +1 to +4 for positive values. Urine albumin levels were measured by a colorimetric test of protein error of a $\mathrm{pH}$ indicator (Free, Rupe, and Metzler, 1957b) with a positive range of +1 to +4 . The serum parameters, analysed by the SMA 12/60, were: calcium, inorganic phosphate, glucose, blood urea nitrogen, uric acid, cholesterol, total protein, albumin, total bilirubin, alkaline phosphatase, lactate dehydrogenase (LDH), and serum glutamic-oxalacetic transaminase (SGOT). The calcium determination, measured in $\mathrm{mg} \%$, was obtained by the Gitelman modification (1967) of the Kessler and Wolfman procedure (1964). The inorganic phosphate test was a modification of the standard $N$ method (Hurst, 1964; Kraml, 1966). The serum glucose levels, one hour after a $50 \mathrm{~g}$-glucose load, were determined by the cupric-neocuprine method following
TABLE I

VARIABLES STUDIED IN DISCRIMINANT ANALYSIS

\begin{tabular}{|c|c|c|}
\hline \multicolumn{2}{|r|}{ Variable } & \multirow{2}{*}{$\begin{array}{l}\text { Explanation } \\
0=\text { no, } 1=\text { yes } \\
0=\text { no, } 1=\text { yes } \\
0=\text { no, } 1=\text { yes }\end{array}$} \\
\hline $\begin{array}{l}\mathbf{X}_{1} \\
\mathbf{X}_{2} \\
\mathbf{X}_{3}\end{array}$ & $\begin{array}{l}\text { History of high blood pressure } \\
\text { History of stroke } \\
\text { History of thyroid disease }\end{array}$ & \\
\hline $\begin{array}{l}\mathbf{X}_{4} \\
\mathbf{X}_{5} \\
\mathbf{X}_{6} \\
\mathbf{X}_{7}\end{array}$ & $\begin{array}{l}\text { Diabetic parent(s) } \\
\text { Diabetic grandparent(s) } \\
\text { Diabetic sib(s) } \\
\text { Diabetic child(ren) }\end{array}$ & $\begin{array}{l}0=\text { no }, 1=\text { yes } \\
0=\text { no, } 1=\text { yes } \\
0=\text { no, } 1=\text { yes } \\
0=\text { no, } 1=\text { yes }\end{array}$ \\
\hline $\mathbf{X}_{8}$ & Sex & $1=$ male, $0=$ female \\
\hline $\begin{array}{l}\mathrm{X}_{9} \\
\mathrm{X}_{10}\end{array}$ & $\begin{array}{l}\text { Age } \\
\text { Age squared }\end{array}$ & $\begin{array}{l}\text { In years } \\
\text { Age in years squared }\end{array}$ \\
\hline $\begin{array}{l}X_{11} \\
X_{12} \\
X_{13} \\
X_{14} \\
X_{15}\end{array}$ & $\begin{array}{l}\text { Height } \\
\text { Weight } \\
\text { Weight/height } \\
\text { Systolic blood pressure } \\
\text { Diastolic blood pressure }\end{array}$ & $\begin{array}{l}\text { In inches } \\
\text { In pounds } \\
\text { Weight in pounds/height in } \\
\text { inches } \\
\mathrm{mm} \mathrm{Hg} \\
\mathrm{mm} \mathrm{Hg}\end{array}$ \\
\hline $\begin{array}{l}\mathrm{X}_{16} \\
\mathrm{X}_{17} \\
\mathrm{X}_{18}\end{array}$ & $\begin{array}{l}\text { Urine sugar } \\
\text { Urine sugar elevated } \\
\text { Urine albumin }\end{array}$ & $\begin{array}{l}0=\text { negative, } 1=\text { positive } \\
\left\{\begin{array}{l}X_{17}=0 \text { if } X_{17} \leq+1 \\
X_{17}=1 \text { if } X_{17}>+1\end{array}\right. \\
0=\text { negative, } 1=\text { positive }\end{array}$ \\
\hline $\begin{array}{l}\mathbf{X}_{19} \\
\mathbf{X}_{20} \\
\mathbf{X}_{21} \\
\mathbf{X}_{22} \\
\mathbf{X}_{23} \\
\mathbf{X}_{24} \\
\mathbf{X}_{25} \\
\mathbf{X}_{26} \\
\mathbf{X}_{27} \\
\mathbf{X}_{29} \\
\mathbf{X}_{30} \\
\mathbf{X}_{31} \\
\mathbf{X}_{32} \\
\mathbf{X}_{33}\end{array}$ & $\begin{array}{l}\text { Calcium } \\
\text { Inorganic phosphorus } \\
\text { Glucose } \\
\text { Glucose } 175 \\
\text { Glucose } 190 \\
\text { Glucose } 205 \\
\text { Blood urea nitrogen } \\
\text { Uric acid } \\
\text { Cholesterol } \\
\text { Total protein } \\
\text { Albumin } \\
\text { Total bilirubin } \\
\text { Alkaline phosphatase } \\
\text { Lactate dehydrogenase (LDH) } \\
\text { Serum glutamic-oxalacetic } \\
\text { transaminase (SGOT) }\end{array}$ & 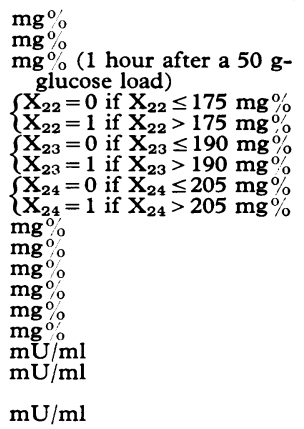 \\
\hline
\end{tabular}

the Bittner, Hall, and McCleary modifications (1963) of the procedures of Brown's method (1961). Known diabetics were not given the standard $50 \mathrm{~g}$ load before testing. Blood urea nitrogen determinations were made after the method of Marsh, Fingerhut, and Miller (1965). The cholesterol test was based on Musser and Ortigoza's automation (1966) of the original method of SobrinhoSimoes (1965). Total protein determination in $\mathrm{mg} \%$ was based on the Ness modification (Ness, Dickerson, and Pastewka, 1965) of the original Rutstein method (Rutstein, Ingenito, and Reynolds, 1954). The $N$ method was used for total bilirubin determination and the alkaline phosphatase measurement in $\mathrm{mU} / \mathrm{ml}$, following the Morgenstern modification (Morgenstern et al, 1965) of the Bessey procedure (Bessey, Lowry, and Brock, 1946). Lactate dehydrogenase activity levels were measured after the procedure of Hochella and Weinhouse (1965). Serum glutamic-oxalacetic dehydrogenase levels, measured in $\mathrm{mU} / \mathrm{ml}$ were determined by the procedure of Morgenstern et al (1966).

Methods of analysis. The primary method employed in the analysis of the data was a discriminant 
function approach after Fisher (1938), applied to diabetic and control groups within races. The discriminant function analysis leads to selection of a parsimonious set of significant variables which differentiates diabetics from healthy controls within each race. After obtaining a discriminant function for each race, the heterogeneity of the coefficients of the functions was tested, taking a common set of variables. The discriminant function was computed according to the multiple regression method outlined by Armitage (1971), and was carried out on the University of Hawaii IBM $360 / 65$ computer using the generalized least squares program, LS, developed by $\operatorname{Dr} M$. P. Mi of the Department of Genetics, University of Hawaii.

On each individual were measured $p$ variables, $x_{1}, x_{2}$, $\ldots, x_{p}$, and $Y$, where $Y$ was defined as 1 for diabetics and 0 for controls. Putting all observations into one group within each race, the stepwise multiple regression of $Y$ on $\mathbf{x}_{1}, \mathbf{x}_{2}, \ldots, \mathbf{x}_{\mathrm{p}}$ provided a linear function of the variables desired. Because of the known effects of sex and age on diabetes, these variables were fitted into the model at the outset. Beginning with the $\mathrm{x}$ variable most highly correlated to the $Y$ variable, selection of significant $x$ variables was made by testing the size of reduction in the residual sum of squares as achieved by the addition of each new variable in the model. The significance of the regression coefficient of each of the variables selected by this procedure was further tested against its standard error. Those variables not found to be significant were deleted and a second cycle of stepwise selection of the remaining variables was initiated ( $\mathrm{Mi}$ and Wong, in preparation).

After selecting a set of variables common to the Caucasian and Japanese groups, the coefficients of the discriminant functions were tested for heterogeneity by the method of Rao (1952) as applied by Chung et al (1969) to determine whether the discriminant functions constructed from the two groups were identical and equally applicable to either race. This would indicate whether factors associated with diabetes have homogeneous relationships with diabetes risk in Japanese and in Caucasians.

\section{Results}

Frequencies of discrete variables under study and differences between diabetic and control groups by race are presented in Table II. Table III gives mean values, standard errors, and the differences between the means of continuous variables for diabetic and control groups by race. The results of the discriminant analysis between diabetics and healthy controls within each race and for races pooled are presented in Table IV, in which the coefficients of the discriminant function (partial regression coefficients) with their standard errors are shown. The column labelled 'stepwise' in Table IV represents those variables which were found to be significant in the stepwise regression analysis after fitting sex, age, and age squared, with $\mathrm{Y}=1$ assigned to the diabetic group, and $Y=0$ to the healthy control group. The coefficients of the final discriminant function model are shown in the next column labelled 'common'.

In the discriminant analysis between diabetics and healthy controls in Japanese and in Caucasians, a considerable degree of similarity is found in the stepwise analysis. History of high blood pressure, diabetic sib, systolic pressure, urine sugar, and blood glucose above $190 \mathrm{mg} / 100 \mathrm{ml}$ were selected after fitting the effects of age, sex, and age squared in both races. In Caucasians only, an additionalo variable, SGOT, was selected as significant in the stepwise regression with the fitted variable ageo squared showing significance at the $5 \%$ level. For: purposes of the test of heterogeneity, a final 'common' model was built by including all variables selected in the stepwise regression in either race and the original fitted variables. The multiple correlation coefficient $\left(\mathbf{R}^{2}\right)$ for the 'common' model was 0.650 in Japanese and 0.711 in

TABLE II

FREQUENCY OF DISCRETE VARIABLES IN CASE AND CONTROL GROUPS BY RACE

\begin{tabular}{|c|c|c|c|c|c|c|}
\hline \multirow[b]{2}{*}{ Variable } & \multicolumn{3}{|c|}{ Japanese } & \multicolumn{3}{|c|}{ Caucasians } \\
\hline & Diabetics & Controls & $\begin{array}{c}\text { Difference } \\
\text { (diabetics - } \\
\text { controls) }\end{array}$ & Diabetics & Controls & $\begin{array}{c}\text { Difference } \\
\text { (diabetics - } \\
\text { controls) }\end{array}$ \\
\hline $\begin{array}{l}\text { History of high blood pressure } \\
\text { History of stroke } \\
\text { History of diabetes } \\
\text { History of thyroid disease } \\
\text { Diabetic parent(s) } \\
\text { Diabetic grandparent(s) } \\
\text { Diabetic sib(s) } \\
\text { Diabetic child(ren) } \\
\text { Males } \\
\text { Positive urine sugar } \\
\text { Positive urine albumin }\end{array}$ & $\begin{array}{l}0.312 \\
0.009 \\
0.936 \\
0.028 \\
0.321 \\
0.018 \\
0.275 \\
0.028 \\
0.569 \\
0.337 \\
0.039\end{array}$ & $\begin{array}{l}0.021 \\
0.002 \\
0.029 \\
0.038 \\
0.142 \\
0.123 \\
0.044 \\
0.000 \\
0.470 \\
0.000 \\
0.000\end{array}$ & $\begin{array}{r}0.291 \\
0.007 \\
0.907 \\
-0.010 \\
0.179 \\
-0.105 \\
0.231 \\
0.028 \\
0.099 \\
0.337 \\
0.039\end{array}$ & $\begin{array}{l}0.290 \\
0.044 \\
0.725 \\
0.101 \\
0.159 \\
0.073 \\
0.087 \\
0.029 \\
0.727 \\
0.364 \\
0.030\end{array}$ & $\begin{array}{l}0.025 \\
0.001 \\
0.005 \\
0.065 \\
0.072 \\
0.133 \\
0.006 \\
0.005 \\
0.530 \\
0.000 \\
0.000\end{array}$ & $\begin{array}{r}0.265 \\
0.043 \\
0.720 \\
0.036 \\
0.087 \\
-0.060 \\
0.081 \\
0.024 \\
0.197 \\
0.364 \\
0.030\end{array}$ \\
\hline
\end{tabular}


TABLE III

MEANS OF CONTINUOUS VARIABLES FOR CASE AND CONTROL GROUPS BY RACE

\begin{tabular}{|c|c|c|c|c|c|c|}
\hline & \multicolumn{3}{|c|}{ Japanese } & \multicolumn{3}{|c|}{ Caucasians } \\
\hline & $\underset{(\text { mean } \pm \text { SE })}{\text { Diabetics }}$ & $\begin{array}{c}\text { Controls } \\
(\text { mean } \pm S E)\end{array}$ & $\begin{array}{c}\text { Difference } \\
\text { (diabetics - } \\
\text { controls) }\end{array}$ & $\underset{(\text { mean } \pm S E)}{\text { Diabetics }}$ & $\begin{array}{c}\text { Controls } \\
\text { (mean } \pm \text { SE })\end{array}$ & $\begin{array}{c}\text { Difference } \\
\text { (diabetics - } \\
\text { controls) }\end{array}$ \\
\hline $\begin{array}{l}\text { Age } \\
\text { Height } \\
\text { Weight } \\
\text { Systolic blood pressure } \\
\text { Diastolic blood pressure } \\
\text { Calcium } \\
\text { Phosphorus } \\
\text { Glucose } \\
\text { Blood urea nitrogen } \\
\text { Uric acid } \\
\text { Cholesterol } \\
\text { Total protein } \\
\text { Albumin } \\
\text { Total bilirubin } \\
\text { Alkaline phosphatase } \\
\text { LDH } \\
\text { SGOT }\end{array}$ & $\begin{array}{c}53.64 \pm 1 \cdot 12 \\
62.04 \pm 0.33 \\
132 \cdot 10 \pm 2 \cdot 29 \\
137.72 \pm 2.01 \\
81 \cdot 47 \pm 1 \cdot 10 \\
9.56 \pm 0.06 \\
3.36 \pm 0.07 \\
196.55 \pm 11.14 \\
15.72 \pm 0.45 \\
5.35 \pm 0.19 \\
253.01 \pm 4.93 \\
7.49 \pm 0.05 \\
4.22 \pm 0.04 \\
0.51 \pm 0.02 \\
67.75 \pm 2.49 \\
158.36 \pm 7.43 \\
37.59 \pm 1.42\end{array}$ & $\begin{array}{r}32 \cdot 12 \pm 0.47 \\
63.54 \pm 0.14 \\
128 \cdot 87 \pm 1 \cdot 02 \\
117 \cdot 81 \pm 0.54 \\
72 \cdot 80 \pm 0.41 \\
9.59 \pm 0.03 \\
3.26 \pm 0.01 \\
122 \cdot 70 \pm 2.07 \\
12.85 \pm 0.23 \\
5 \cdot 20 \pm 0.09 \\
217.23 \pm 2.55 \\
7.44 \pm 0.03 \\
4.32 \pm 0.03 \\
0.50 \pm 0.01 \\
51.55 \pm 1.20 \\
131 \cdot 01 \pm 1.78 \\
29.68 \pm 0.60\end{array}$ & $\begin{array}{r}21.52 \\
-1.50 \\
3.23 \\
19 \cdot 91 \\
8.67 \\
-0.03 \\
0.10 \\
73.85 \\
2.87 \\
0.15 \\
37 \cdot 78 \\
0.05 \\
-0.10 \\
0.01 \\
16.20 \\
27.35 \\
7.91\end{array}$ & $\begin{array}{r}55.65 \pm 1.55 \\
67.68 \pm 0.47 \\
171.42 \pm 4.10 \\
147.15 \pm 3.25 \\
80.91 \pm 1.62 \\
9.70 \pm 0.06 \\
3.01 \pm 0.08 \\
221.44 \pm 13.73 \\
16.54 \pm 0.63 \\
5.77 \pm 0.19 \\
230.68 \pm 5.04 \\
7.21 \pm 0.06 \\
4.07 \pm 0.05 \\
0.57 \pm 0.03 \\
61.78 \pm 2.57 \\
140.14 \pm 4.41 \\
41.98 \pm 3.04\end{array}$ & $\begin{array}{r}30.30 \pm 0.37 \\
67 \cdot 42 \pm 0.12 \\
148 \cdot 03 \pm 0.91 \\
117.64 \pm 0.40 \\
70.52 \pm 0.32 \\
9.64 \pm 0.02 \\
3.31 \pm 0.03 \\
113.66 \pm 1.53 \\
14.26 \pm 0.19 \\
5.31 \pm 0.07 \\
204.83 \pm 2.06 \\
7.26 \pm 0.02 \\
4.32 \pm 0.02 \\
0.50 \pm 0.01 \\
48.04 \pm 0.74 \\
128 \cdot 32 \pm 1.24 \\
30.59 \pm 0.42\end{array}$ & $\begin{array}{r}25.35 \\
0.26 \\
23.38 \\
29.51 \\
10.39 \\
0.06 \\
-0.30 \\
107.78 \\
2.28 \\
0.46 \\
25.85 \\
-0.05 \\
-0.25 \\
0.07 \\
13.74 \\
11.82 \\
11.39\end{array}$ \\
\hline
\end{tabular}

TABLE IV

DISCRIMINATIONS BETWEEN CASE AND HEALTHY CONTROLS BY RACE

\begin{tabular}{|c|c|c|c|c|c|}
\hline & \multicolumn{2}{|c|}{ Japanese } & \multicolumn{2}{|c|}{ Caucasians } & \multirow{2}{*}{$\begin{array}{c}\text { Both Races } \\
\text { Common }\end{array}$} \\
\hline & Stepwise & Common & Stepwise & Common & \\
\hline $\begin{array}{l}\text { Fitted } \\
\text { Age } \\
\text { Sex } \\
\text { Age }^{2}\end{array}$ & $\begin{array}{r}-0.0014 \pm 0.0063 \\
0.0595 \pm 0.0334 \\
0.0001 \pm 0.00007\end{array}$ & $\begin{aligned}-0.0017 & \pm 0.0063 \\
0.0471 & \pm 0.0339 \\
0.0001 & \pm 0.00007\end{aligned}$ & $\begin{array}{r}-0.0056 \pm 0.0037 \\
0.0021 \pm 0.0210 \\
0.0001 \pm 0.00004 *\end{array}$ & $\begin{aligned}-0.0056 & \pm 0.0037 \\
0.0021 & \pm 0.0210 \\
0.0001 & \pm 0.00004 *\end{aligned}$ & $\begin{array}{r}-0.0048 \pm 0.0034 \\
0.0081 \pm 0.0189 \\
0.0001 \pm 0.00004\end{array}$ \\
\hline $\begin{array}{l}\text { Study variables } \\
\text { History of high blood pressure } \\
\text { History of stroke } \\
\text { History of thyroid disease }\end{array}$ & $\begin{array}{c}0.2040 \pm 0.0552 t \\
=\end{array}$ & $\begin{array}{c}0.1911 \pm 0.0555 t \\
-\end{array}$ & $\begin{array}{c}0 \cdot 1925 \pm 0.0394 \dagger \\
- \\
\end{array}$ & $\begin{array}{c}0.1925 \pm 0.0394 \dagger \\
-\end{array}$ & $\begin{array}{c}0.1948 \pm 0.0332 t \\
-\end{array}$ \\
\hline $\begin{array}{l}\text { Diabetic parent(s) } \\
\text { Diabetic grandparent(s) } \\
\text { Diabetic sib(s) } \\
\text { Diabetic child(ren) } \\
\end{array}$ & $0.2366 \pm 0.0525 t$ & $0.2446 \pm 0.0525 t$ & $0.1925 \pm 0.0652 t$ & $0.1925 \pm 0.0652+$ & $0.265 \overline{2 \pm} 0.0381 t$ \\
\hline $\begin{array}{l}\text { Height } \\
\text { Weight } \\
\text { Weight/height } \\
\text { Systolic blood pressure } \\
\text { Diastolic blood pressure }\end{array}$ & $\begin{array}{c}\bar{Z} \\
0.0041 \pm 0.0010 t \\
\end{array}$ & $\begin{array}{c}\bar{Z} \\
0.0041 \pm 0.0010 t\end{array}$ & $\begin{array}{c}\bar{Z} \\
\overline{0} \\
\underline{-} \\
\end{array}$ & $0.0023 \pm 0.0007 t$ & Z \\
\hline $\begin{array}{l}\text { Urine sugar } \\
\text { Urine sugar elevated } \\
\text { Urine albumin } \\
\text { Calcium } \\
\text { Phosphorus } \\
\text { Glucose } \\
\text { Glucose } 175 \\
\text { Glucose } 190 \\
\text { Glucose } 205 \\
\text { Blood urea nitrogen } \\
\text { Uric acid } \\
\text { Cholestero! } \\
\text { Total protein } \\
\text { Albumin } \\
\text { Total bilirubin } \\
\text { Alkaline phosphatase } \\
\text { LDH } \\
\text { SGOT }\end{array}$ & $\begin{array}{c}0.2642 \pm 0.0621 t \\
= \\
= \\
= \\
=34570.0585 t \\
= \\
= \\
= \\
= \\
=\end{array}$ & $\begin{array}{c}0.2410 \pm 0.0626 t \\
= \\
= \\
= \\
0.3369 \pm 0.0584 t \\
= \\
= \\
= \\
= \\
0.0029 \pm 0.0016\end{array}$ & $\begin{array}{c}0.1893 \pm 0.0559 t \\
= \\
= \\
0.6055 \pm 0.0482 t \\
= \\
= \\
= \\
= \\
0.0027 \pm 0.0008 t\end{array}$ & $\begin{array}{c}0.1893 \pm 0.0559 t \\
= \\
= \\
0.6055 \pm 0.0482 t \\
= \\
= \\
= \\
= \\
= \\
\end{array}$ & $\begin{array}{c}0.2427 \pm 0.0413 t \\
= \\
= \\
= \\
0.4513 \pm 0.0376 t \\
= \\
= \\
= \\
= \\
= \\
=0.029 \pm 0.0008 t\end{array}$ \\
\hline $\begin{array}{l}\mathrm{R}^{2} \\
\text { Total no. of cases } \\
\text { Total no. of controls } \\
\text { Intercept }\end{array}$ & $\begin{array}{c}0.6461 \\
109 \\
173 \\
-0.5726\end{array}$ & $\begin{array}{c}0.6501 \\
109 \\
173 \\
-0.6416\end{array}$ & $\begin{array}{c}0.7113 \\
69 \\
326 \\
-0 \cdot 2723\end{array}$ & $\begin{array}{c}0.7113 \\
69 \\
326 \\
-0.2723\end{array}$ & $\begin{array}{c}0.6720 \\
178 \\
499 \\
-0.4303\end{array}$ \\
\hline
\end{tabular}

$* \mathrm{p} \leq 0.05$.

$+\mathrm{p} \leq 0.01$. 
Caucasians indicating a high degree of discrimination between the diabetic and control groups.

In both racial groups, diabetics exhibited significantly higher systolic blood pressure and higher frequency of a history of high blood pressure than controls. The apparent partial statistical independence of the two factors may be due to the recency of onset of the disease or individual differences in perception of disease history. Diastolic blood pressure was not selected in the stepwise model in either racial group, nor were any of the other remaining anthropometric variables. Of the variables related to family history of diabetes among different degrees of relatives, the presence of a diabetic sib was found to be the best discriminator. SGOT was significant in the stepwise selection in Caucasians but not in Japanese. This unexpected finding points to a possible racial difference in disease pattern.

It is of interest to note that the rigorous criterion of urine sugar elevation based on $\mathrm{X}_{17}$ has yielded no more critical information than a simple positive urine sugar test result $\left(\mathbf{X}_{16}\right)$ in discrimination between diabetics and controls in either race. In both Japanese and Caucasian groups, glucose elevation based on the level of $190 \mathrm{mg} \%$ ( 2.5 standard deviations above the mean) appeared to give best discrimination between diabetics and controls among the blood glucose variables. It should also be noted that both urine sugar and blood glucose elevation based on $190 \mathrm{mg} \%$ maintain a degree of independence in their contribution to the discrimination.

The result of the heterogeneity test of the nine coefficients of the discriminant function is presented in Table V. According to the result the discriminant functions for the Japanese and Caucasian groups are significantly heterogeneous.

TABLE V

TEST OF HETEROGENEITY OF PARTIAL REGRESSION COEFFICIENTS

\begin{tabular}{l|c|c|c|c|c}
\hline & \multicolumn{2}{|c|}{ Sum of Squares } & \multicolumn{2}{c|}{ DF } & F \\
\cline { 2 - 5 } & Reg. & Resid. & Reg. & Resid. & \\
\hline Japanese & 37.5320 & 20.2020 & 9 & 272 & - \\
\hline Caucasians & 34.1867 & 13.8741 & 9 & 385 & - \\
\hline $\begin{array}{l}\text { Within Japanese and } \\
\text { within Caucasians }\end{array}$ & 73.4333 & 35.8429 & 9 & 666 & 3.79 \\
\hline $\begin{array}{l}\text { Japanese and } \\
\text { Caucasians }\end{array}$ & 71.7187 & 34.0761 & 18 & 657 & - \\
\hline
\end{tabular}

$F=\frac{35 \cdot 8429-34 \cdot 0761}{9} / \frac{34 \cdot 0761}{657}=3 \cdot 7895^{*}(d f=9 ; 657)$.

$* \mathrm{p} \leq 0.01$.
TABLE VI

STANDARDIZED REGRESSION COEFFICIENTS

\begin{tabular}{l|c|c}
\hline \multicolumn{1}{c|}{ Variable } & Japanese & Caucasians \\
\hline Age $^{2}$ & 0.3380 & 0.3608 \\
Glucose 190 & 0.2625 & 0.4996 \\
Urine sugar & 0.1731 & 0.1217 \\
Sib diabetic & 0.1714 & 0.0823 \\
Systolic blood pressure & 0.1672 & 0.1185 \\
History of high blood pressure & $0 \cdot 1376$ & 0.1462 \\
SGOT & 0.0704 & 0.0939 \\
Age & 0.0538 & 0.2249 \\
Sex & 0.0521 & 0.0030 \\
\hline
\end{tabular}

Some differences between the final models of the discriminant functions may also be noted in the different relative orders of the standardized regression coefficients in Japanese and Caucasian groups, presented in Table VI. Age (squared) exhibited the highest coefficient in the Japanese model, followed by glucose over $190 \mathrm{mg} \%$. The order of prominence of these two variables is reversed, however, in the Caucasian group. The presence of a diabetic sib, in the Japanese model, ranked fourth in importance, while in Caucasians it ranked eighth out of the nine variables in the model. Thus, the variables in the final model seem to contribute differently to the discriminant equations in the Japanese and Caucasian groups.

Table VII shows the mean blood glucose levels by age for both Japanese and Caucasian groups. The data include the total screened sample. As ex pected, the mean levels of blood glucose steadily? increase with age in both groups, but the rate of increase appears to be greater in Japanese than in Caucasians. This may be an underlying factor in the observed racial differences in the relationship of age and blood glucose levels with diabetic risk. It is also of interest to observe that age effects are reflected in increases in both the mean and the variance of glucose. When variation is expressed as coefficient of variation (standard deviation $/$ mean), it still shows a steady trend of increase with age in both groups, suggesting that an erratic pattern of glucose metabolism may be frequent with age.

\section{Discussion}

The findings of this investigation point to heterogeneity in diabetes disease pattern between Japanese and Caucasian groups living in Hawaii. This is in general evidenced by significant heterogeneity between the two racial groups in the coefficients of the discriminant function in the final 'common' models. Differences were also noted in the magnitude and ranking of the standardized regression coefficients between the groups. 
TABLE VII

GLUCOSE TOLERANCE IN JAPANESE AND CAUCASIANS BY AGE

\begin{tabular}{|c|c|c|c|c|c|c|c|}
\hline \multirow{2}{*}{ Age (yr) } & \multicolumn{3}{|c|}{ Japanese } & \multicolumn{3}{|c|}{ Caucasians } & \multirow{2}{*}{$\begin{array}{c}\text { Mean } \\
\text { Difference } \\
\text { (Japanese- } \\
\text { Caucasians) }\end{array}$} \\
\hline & Mean & $\mathrm{SD}$ & $\begin{array}{c}\text { Coefficient } \\
\text { of } \\
\text { Variation }\end{array}$ & Mean & SD & $\begin{array}{c}\text { Coefficient } \\
\text { of } \\
\text { Variation }\end{array}$ & \\
\hline $\begin{array}{r}0-20 \\
21-30 \\
31-40 \\
41-50 \\
51-60 \\
61-70 \\
71-80 \\
81+\end{array}$ & $\begin{array}{l}114 \cdot 29 \\
115 \cdot 29 \\
127.40 \\
137 \cdot 39 \\
146.30 \\
156.73 \\
176.67 \\
160.83\end{array}$ & $\begin{array}{l}27 \cdot 20 \\
29 \cdot 08 \\
50 \cdot 12 \\
46 \cdot 83 \\
59 \cdot 67 \\
59 \cdot 22 \\
74 \cdot 50 \\
55 \cdot 28\end{array}$ & $\begin{array}{l}0.238 \\
0.252 \\
0.393 \\
0.341 \\
0.408 \\
0.378 \\
0.422 \\
0.344\end{array}$ & $\begin{array}{l}101 \cdot 71 \\
110.11 \\
119.68 \\
130.36 \\
134.64 \\
148.72 \\
152.72 \\
163.89\end{array}$ & $\begin{array}{l}28 \cdot 97 \\
30 \cdot 54 \\
35 \cdot 54 \\
45 \cdot 34 \\
47 \cdot 64 \\
53 \cdot 76 \\
54 \cdot 11 \\
49 \cdot 90\end{array}$ & $\begin{array}{l}0.285 \\
0.277 \\
0.297 \\
0.348 \\
0.354 \\
0.362 \\
0.354 \\
0.305\end{array}$ & $\begin{array}{r}12.58 \\
5.18 \\
7.72 \\
7.03 \\
11.66 \\
8.01 \\
23.95 \\
-3.06\end{array}$ \\
\hline
\end{tabular}

The following specific points of difference and similarity may be noted. None of the indices of obesity was discriminatory between diabetics and controls in either race over and above the variables mentioned, after adjustment for age and sex effects. However, this does not mean necessarily that obesity is not aetiologically related to diabetes. In Caucasians, where diabetics were significantly heavier than controls (Table III), weight and weight/height were found to be correlated to existing blood glucose and urine sugar levels, indicating a possible indirect relationship to the subsequent development of diabetes. In Japanese, however, no such correlations were found. Japanese healthy controls and diabetics did not differ significantly in weight or height in this study. In Japan, however, obesity appears to be more frequent in adult-onset diabetics than in non-diabetics (Shigeta et al, 1971).

In the final models in both racial groups, a significant role of systolic blood pressure is consistent with findings of hypertension as a diabetic complication in both Japanese and Caucasians (Bauer, 1967; Kuzuya and Kosaka, 1971). Diastolic blood pressure, which was significantly higher in diabetics than controls (Table III) in both races, did not make an additional contribution to the discrimination.

Among relatives, diabetic sibs alone were found to be significant in discrimination in both racial groups. Being closest in age to the diabetic case and most similar in various sociological parameters, the sib among first-degree relatives may reflect familial tendencies caused by common environmental factors as well as the ease at which ascertainment is made. Diabetic sibs and parents were significantly more frequent among Japanese than among Caucasians, within diabetic and within control groups, while the frequency of diabetic grandparents and diabetic children did not differ significantly between racial groups. The lack of difference between races in frequency of diabetic children is not surprising, as diabetes is predominantly a maturity-onset disease.
The excess of diabetics in sib and also parental generations in Japanese cases and controls as compared to those in Caucasians is consistent with observed higher risk of Japanese to diabetes. The age adjusted prevalence rates of Japanese and Caucasians for the Straub data were $35 \cdot 7 / 1000$ and $12 \cdot 9 / 1000$, respectively. This is consistent with adjusted prevalence rates found by Sloan (1963). The information on the frequency of diabetic grandparents is probably not reliable, as many grandparents of adult Japanese would have been living in Japan.

Apart from the blood glucose and urine sugar variables of disease manifestation, the only other biochemical parameter found to make significant independent contribution to the discrimination was SGOT; this was significant in the stepwise selection in Caucasians but not in Japanese. However, it should be pointed out that both racial groups had significantly higher SGOT levels in the case groups when the differences were tested individually. Elevated SGOT levels have been associated with adverse effects of oral hypoglycaemic agents on the liver (Lilly Research Laboratories, 1967).

The current investigation of factors associated with diabetes disease pattern is retrospective in nature and as such may be of limited value in clinical diagnosis. Among cases nearly all were previously known diabetics. Variables such as blood glucose and urine sugar levels in the cases studied, in most instances, would have been modified by treatment and do not accurately reflect the situation in previously undiagnosed cases. Among controls, healthy individuals rather than nondiabetics were selected. Due to peculiarities of data collection, the Caucasian non-diabetic group included a higher proportion of persons with medical problems and clinical symptoms than would be expected from a random sample of a non-diabetic population. Thus for purposes of consistency a healthy control was selected in each racial group.

It is clear from the discriminant analysis that the 
factors associated with diabetes appear to have different relative importance in the cause of diabetes manifestation in the two racial groups. Though it is difficult to establish the precise interrelationships among factors, it does appear that the Japanese and Caucasians respond differently to age with respect to glucose metabolism. This would indicate the desirability of further investigations into possible genetic factors and differences in diet between the two groups as related to the observed differential age effects.

\section{REFERENCES}

American Diabetes Association (1960). Recent statistics on diabetes. Diabetes, 9, 500-503.

Armitage, P. (1971). Statistical Methods in Medical Research. Blackwell Scientific, Oxford.

Bauer, M. L. (1967). Characteristics of Persons with Diabetes, United States, fuly 1964-7 fune 1965. Vital and Health Statistics Series 10, No. 40. United States Public Health Service, Washington.

Bell, E. T. (1960). Diabetes Mellitus, A Clinical and Pathological Study of 2529 Cases. Thomas, Springfield, Illinois.

Bessey, O. A., Lowry, O. H., and Brock, M. J. (1946). A method for the rapid determination of alkaline phosphatase with five cubic millimeters of serum. Fournal of Biological Chemistry, 164, 321329.

Bittner, D. L., Hall, S. G., and McCleary, M. L. (1963). A method for determination of uric acid, using the cupric-phenanthroline indicator system. American fournal of Clinical Pathology, 40, 423-424.

Brown, M. E. (1961). Ultra-micro sugar determinations using 2 , 9-dimethyl-1, 10-phenanthroline hydrochloride (neocuproine). Diabetes, 10, 60-62.

Chung, C. S., Bassett, D. R., Moellering, R. C., Jr, Rosenblatt, G., Stokes, J., III, and Yoshizaki, H. (1969). Risk factors for coronary heart disease in Hawaiian and Japanese males in Hawaii, fournal of Medical Genetics, 6, 59-66.

Fisher, R. A. (1938). The statistical utilization of multiple measurements. Annals of Eugenics, 8, 376-386.

Free, A. H., Adams, E. C., Kercher, M. L., Free, H. M., and Cook, M. H. (1957a). Simple specific test for urine glucose. Clinical Chemistry, 3, 163-168.

Free, A. H., Rupe, C. O., and Metzler, I. (1957b). Studies with a new colorimetric test for proteinuria. Clinical Chemistry, 3, 716727.

Gitelman, H. J. (1967). An improved automated procedure for the determination of calcium in biological specimens. Analytical Biochemistry, 18, 521-531.

Hochella, N. J. and Weinhouse, S. (1965). Automated assay of lactate dehydrogenase in urine. Analytical Biochemistry, 13, 322335.

Hurst, R. O. (1964). The determination of nucleotide phosphorus with a stannous chloride-hydrazine sulphate reagent. Canadian Fournal of Biochemistry, 42, 287-292.

Kessler, G. and Wolfman, M. (1964). An automated procedure for the simultaneous determination of calcium and phosphorus. Clinical Chemistry, 10, 686-703.
Kraml, M. (1966). A semi-automated determination of phospholipids. Clinica Chimica Acta, 13, 442-448.

Kuzuya, N. and Kosaka, K. (1971). Diabetes in Japan. In Diabetes Mellitus in Asia, 1970, ed. by S. Tsuji and M. Wada, pp. 11-21. Excerpta Medica (ICS No. 221), Amsterdam.

Lilly Research Laboratories (1967). Diabetes Mellitus, 7th ed. Eli Lilly, Indianapolis.

Lind, A. W. (1967). Hawaii's People. University of Hawaii Press, Honolulu.

Marsh, W., Fingerhut, B., and Miller, H. (1965). Automated and manual direct methods for the determination of blood urea. Clinical Chemistry, 11, 624-627.

Mi, M. P. and Wong, J. C. Computer Programs for Statistical Analysis of Biomedical Data. Mimeographed.

Morgenstern, S., Kessler, G., Auerbach, J., Flor, R. V., and Klein, B. (1965). An automated p-nitrophenylphosphate serum alkaline phosphatase procedure for the autoanalyzer. Clinical Chemistry, $11,876-888$.

Morgenstern, S., Oklander, M., Auerbach, J., Kaufman, J., and Klein, B. (1966). Automated determination of glutamic oxaloacetic transaminase. Clinical Chemistry, 12, 95-111.

Musser, A. W. and Ortigoza, C. (1966). Automated determination of uric acid by the hydroxylamine method. Technical Bulletin of the Registry of Medical Technologists, 36, 21-25.

Ness, A. T., Dickerson, H. C., and Pastewka, J. V. (1965). The determination of human serum albumin by its specific binding of the anionic dye, 2-(4'hydroxybenzeneazo)-benzoic acid. Clinica Chimica Acta, 12, 532-541.

Okamoto, K., Hazama, F., and Yamasaki, T. (1971). Pathology of diabetes mellitus in Japan. In Diabetes Mellitus in Asia, 1970, ed. by S. Tsuji and M. Wada, pp. 106-110. Excerpta Medica (ICS No. 221), Amsterdam.

Rao, C. R. (1952). Advanced Statistical Methods in Biometric Research. Wiley, New York.

Rudnick, P. A. and Anderson, P. S. (1962). Diabetes mellitus in Hiroshima, Japan: a detection program and clinical survey. Diabetes, 11, 533-543.

Rutstein, D. D., Ingenito, E. F., and Reynolds, W. E. (1954). The determination of albumin in human blood plasma and serum. A method based on the interaction of albumin with an anionic dye2-(4'-hydroxy-benzeneazo) benzoic acid. Fournal of Clinical Investigation, 33, 211-221.

Shigeta, Y., Oji, N., Shichiri, M., and Hoshi, M. (1971). Pathoce genesis and clinical characteristics of obese diabetics in Japan. In Diabetes Mellitus in Asia, 1970, ed. by S. Tsuji and M. Wada, pp. 159-167. Excerpta Medica (ICS No. 221), Amsterdam.

Sloan, N. M. (1963). Ethnic distribution of diabetes mellitus in Hawaii. Fournal of the American Medical Association, 183, 419424.

Sobrinho-Simoes, M. S. (1965). A sensitive method for the measurement of serum uric acid using hydroxylamine. Fournal of Laboratory and Clinical Medicine, 65, 665-668.

Stemmerman, G. N. (1970). Patterns of disease among Japanese living in Hawaii. Archives of Environmental Health, 20, 266-273.

Tillotson, J. L., Kato, H. Nichaman, M. Z, Miller, D. C., Gay, M. L., Johnson, K. G., and Rhoads, G. G. (1973). Epidemiology of coronary heart disease and stroke in Japanese men living in Japan, Hawaii and California: methodology for comparison of diet. American fournal of Clinical Nutrition, 26, 177-184.

Tsuji, S. and Wada, M. (eds.) (1971). Diabetes Mellitus in Asia, 1970. Excerpta Medica (ICS No. 221), Amsterdam.

Wenkam, N. S., and Wolff, R. J. (1970). A half century of changing food habits among Japanese in Hawaii. Fournal of the American Dietetics Association, 57, 29-32. 